\title{
PENGEMBANGAN MEDIA PEMBELAJARAN MEMBACA BAHASA INGGRIS SMP BERBASIS WEB
}

\author{
Kandung Supriyono, Sugirin \\ Dinas Dikpora Gunungkidul, Universitas Negeri Yogyakarta \\ kandungs@yahoo.com, sugirin@uny.ac.id
}

\begin{abstract}
Abstrak
Penelitian ini bertujuan untuk mengembangkan media pembelajaran membaca Bahasa Inggris SMP berbasis web yang memenuhi unsur kelayakan dan keefektifan. Penelitian dan pengembangan ini dilakukan dalam lima tahap, yaitu: (1) analisis kebutuhan, (2) perencanaan evaluasi, (3) pengembangan serentak, (4) implementasi penuh, dan (5) evaluasi sumatif. Media pembelajaran membaca bahasa Inggris SMP berbasis web yang dihasilkan dapat digunakan sebagai media pembelajaran bagi siswa dan guru. Hal ini didasarkan pada rata-rata skor evaluasi ahli materi sebesar 3,94 atau kategori baik, dan ahli media sebesar 4,21 atau kategori baik. Sementara itu, hasil uji coba peserta didik memperoleh skor rata-rata sebesar 4,13 dengan kategori baik. Media tersebut telah memehuhi standar keefektifan untuk pembelajaran, dibuktikan dengan hasil pretes dan postes. Nilai rata-rata pretes sebesar 43 , sedangkan nilai rata-rata postes sebesar 86 , mengalami peningkatan sebesar $46 \%$. Tingkat ketuntasan $4 \%$ menjadi $90 \%$ atau mengalami kenaikan sebesar $86 \%$.
\end{abstract}

Kata kunci: media pembelajaran, pengembangan, berbasis web, bahasa inggris

\section{DEVELOPING WEB-BASED ENGLISH READING MEDIA FOR SMP STUDENTS}

\author{
Kandung Supriyono, Sugirin \\ Dinas Dikpora Gunungkidul, Universitas Negeri Yogyakarta \\ kandungs@yahoo.com, sugirin@uny.ac.id
}

\begin{abstract}
This study aims to develop feasible and effective web-based English reading media for SMP students. This Research and development was carried out in five stages, namely: (1) needs analysis, (2) evaluation plans, (3) product development, (4) product Implementation, and (5) Summative evaluation. The media produced is categorized as good quality to be used by students and teachers. The subject-matter expert evaluation shows the average score of 3.94 or good category. The media-expert validation is 4.21 or good category. The field test is 4.13 or good category. The media is effective for learning. It can be seen from the results of the pre-test and post-test which shows a significant increase. The average score of the pretest is 43, while the average post-test is 86, an increase of $46 \%$. The mastery level is from $4 \%$ to $90 \%$ or an increase of $86 \%$.
\end{abstract}




\section{Pendahuluan}

Bahasa Inggris, bahasa internasional yang di Indonesia diajarkan sebagai bahasa asing, sangat berperan di berbagai tempat dan bidang. Pembelajaran bahasa Inggris di SMP/ MTs ditargetkan agar peserta didik dapat mencapai tingkat functional yakni berkomunikasi secara lisan dan tulis untuk menyelesaikan masalah seharihari. Kemampuan berkomunikasi dalam pengertian yang utuh adalah kemampuan berwacana, yakni kemampuan memahami dan/atau menghasilkan teks lisan dan/ atau tulis yang direalisasikan dalam empat keterampilan berbahasa, yaitu mendengarkan, berbicara, membaca dan menulis. Keempat keterampilan inilah yang digunakan untuk menanggapi atau menciptakan wacana dalam kehidupan bermasyarakat. Oleh karena itu, mata pelajaran Bahasa Inggris diarahkan untuk mengembangkan keterampilan keterampilan tersebut agar lulusan mampu berkomunikasi dan berwacana dalam bahasa Inggris pada tingkat literasi tertentu (Depdiknas, 2006).

Untuk memperluas pengetahuannya, siswa SMP yang telah menyelesaikan belajarnya diharapkan, paling tidak, memiliki motivasi dan kemampuan untuk membaca buku, majalah, atau tulisan lain dalam bahasa Inggris. Sedangkan mereka yang akan melanjutkan studinya akan memiliki kemampuan dasar struktur, kosa kata dan pengetahuan lain untuk mempelajari bahasa Inggris lanjutan, untuk membantu mereka menguasai ilmu pengetahuan dan teknologi yang sangat diperlukan di era global ini.

Meskipun Bahasa Inggris memiliki peran yang sangat penting seperti disebutkan di atas nampaknya pengajaran bahasa Inggris di Indonesia masih belum memuaskan. Hal ini dapat dilihat dari fakta bahwa siswa yang telah belajar dua atau tiga tahun masih mengalami kesulitan untuk mengucapkan kata kata dalam bahasa Inggris. Demikian juga kemampuan mengerjakan soal UN yang dari tahun ke tahun selalu menjadi masalah secara nasional.
Sebagai contoh hasil UN bahasa Inggris SMP 1 Ponjong dari tahun pelajaran 2006/2007 sampai dengan 2010/ 2011 berturut-turut 6,53, 6,43, 6,33, 6,54, dan 6,39. Nilai ini masih di bawah batas tuntas yang ditetapkan sekolah. Banyak siswa tidak lulus karena nilai UN bahasa Inggris belum mencapai standar kompetensi kelulusan. Nilai UN Bahasa Inggris juga masih lebih rendah dari Mata pelajaran UN lainnya. Perolehan nilai UN dari tahun ke tahun dirangkum dalam grafik yang disajikan pada Gambar 1.

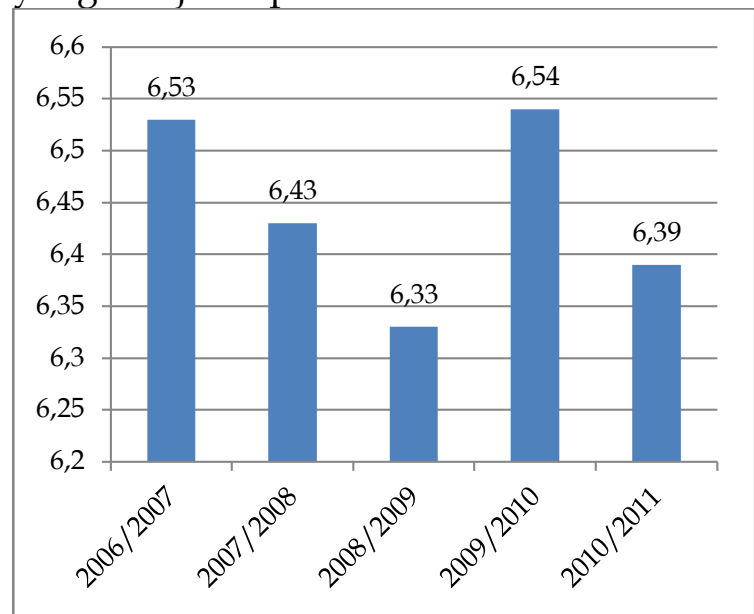

Gambar 1. Nilai Ujian Nasional Bahasa Inggris SMP 1 Ponjong Tahun 2006/2007 sampai dengan Tahun 2010/2011

Lebih memprihatinkan adalah hasil ujian akhir semester gasal dan genap tahun 2010/ 2011 untuk kelas VII mencapai 3,42 dan 4,76, kelas VIII mencapai 4,21 dan 5,28, sedangkan kelas IX mencapai 4,26 untuk semester gasal, seperti disajikan pada Gambar 2

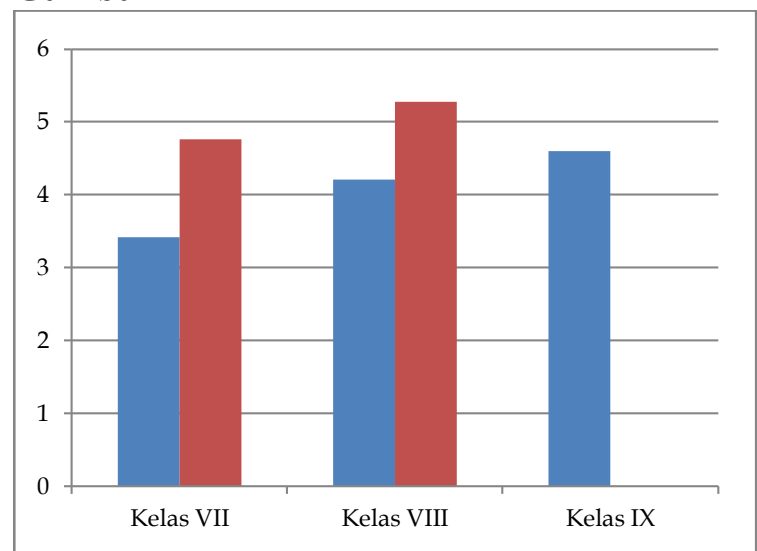

Gambar 2. Nilai Ulangan Akhir Semester Bahasa Inggris SMP 1 Ponjong Tahun 2010/2011 
Memang banyak faktor yang mempengaruhi yang mempengaruhi belajar bahasa ke dua atau bahasa asing. William Francis Mackey (1985) mengatakan bahwa faktor utama adalah: 1) Faktor linguistik, 2) Faktor sosial, berkaitan dengan: a) Seringnya berlatih atau menggunakan bahasa tersebut. b) Sejumlah faktor yang berbeda seperti waktu, penggunaan media belajar, sikap, tekanan dan ketrampilan. (3) Faktor psikologi berkaitan dengan usia, motivasi, intelegensi dan dorongan

Untuk itu harus dicari cara untuk membangkitkan motivasi belajar siswa, antara lain dengan meyakinkan siswa tentang pentingnya belajar Bahasa Inggris, materi otentik dan penyajian yang bervariasi, dan metode yang menarik, memberikan kesempatan kepada siswa untuk berperan lebih aktif dalam proses belajar, dan mendekatkan materi dengan pengalaman belajar siswa.

Untuk bisa menyajikan materi pembelajaran seperti yang dituntut tersebut diperlukan hadirnya teknologi pembelajaran yang tepat, yang salah satunya adalah teknologi informasi yang berbasis komputer. Dewasa ini komputer diyakini sebagai media serba bisa. Media ini dapat menyajikan materi pembelajaran yang menarik, bervariasi, menjangkau materi yang lebih luas. Komputer juga bisa "mendatangkan" native speaker yang diperlukan dalam pembelajaran bahasa asing dalam bentuk video, juga mendatangkan berbagai benda sebenarnya dalam bentuk virtual, sehingga pembelajaran berbasis kontek lebih mudah disajikan. Komputer sebagai salah satu produk teknologi dinilai tepat digunakan sebagai alat bantu pengajaran (Surjono, 2010). Siswa mempelajari salah satu bidang ilmu dengan bantuan komputer.

Penggunan media membelajaran dapat dipergunakan untuk memanipulasi seringnya kontak dengan bahasa yang dipelajari dan meningkatkan motivasi belajar. Tetapi masih sangat sedikit media pembelajaran yang sesuai dengan kurikulum yang berlaku dan karakteristik peserta didik, untuk itu sangat diperlukan adanya pengembangan dimaksud.
Di samping itu, lingkungan bahasa juga berfungsi sebagai input bahasa. Menurut Krashen (1981) dalam Widiati (2010) dalam pembelajar bahasa memperoleh bahasa hanya melalui satu cara, yaitu melalui exposure dalam kehidupan sehari-hari. Semakin banyak input yang didapatkan pembelajar, semakin besar kesempatan dia menguasai bahasa tersebut. Penambahan kesempatan mendapatkan expo-sure Bahasa Inggris melalui penumbuhkembangan kemandirian belajar di luar jam formal menjadi sebuah keharusan, dan salah satunya menggunakan pembelajaran berbasis Web.

Penelitian ini bertujuan untuk mengembangkan media pembelajaran membaca Bahasa Inggris SMP berbasis web yang layak dan efektif. Hal ini dimaksudkan untuk memenuhi kekurangan media yang memungkinkan peserta didik lebih banyak berlatih.

Penelitian ini adalah penelitian dan pengembangan. Menurut Kamus Besar Bahasa Indonesia, pengembangan adalah proses, cara, perbuatan mengembangkan, dan mengembang-kan berarti menjadikan maju (baik, sempurna, dsb) menjadikan sesuatu lebih baik atau sempurna. Menurut Gay (1990) penelitian pengembangan adalah suatu usaha untuk mengembankan suatu produk yang efektif untuk digunkan sekolah, dan bukan untuk menguji teori. Dalam penelitian ini yang dimaksud pengembangan adalah suatu proses, cara, perbuatan untuk membuat media pelajaran membaca bahasa Inggris menjadi lebih baik.

Penelitian ini untuk menjawab pertanyaan-pertanyaan sebagai berikut: (1) bagaimana mengembangkan media pembelajaran membaca Bahasa Inggris SMP berbasis web yang memenuhi standar kelayakan? (2) bagaimana kelayakan media pembelajaran membaca Bahasa Inggris SMP berbasis web ditinjau dari aspek instruksional? (3) bagaimana kelayakan media pembelajaran membaca Bahasa Inggris SMP berbasis web ditinjau dari aspek isi? (4) bagaimana kelayakan media pembelajaran membaca Bahasa Inggris SMP berbasis web ditinjau dari aspek tampilan? 
(5) bagaimana kelayakan media pembelajaran membaca Bahasa Inggris SMP berbasis web ditinjau dari aspek pemrograman? (6) bagaimana keefektifan media yang dikembangkan?

Media pembelajaran berbasis web sering disebut dengan e-learning yang memungkinkan interaksi antara siswa satu dengan siswa lain, siswa dengan guru, dan siswa dengan komputer secara klasikal maupun individual. Siswa bisa memilih materi yang sesuai dengan tingkatannya, materi yang belum dikuasai. Siswa dapat menguji pemahamannya dengan mengerjakan tes atau kuis yang menyertai materi, atau mengetikkan sesuatu yang diminta oleh program. Siswa dapat berkomunikasi dengan siswa lain atau guru melalui layanan chatting antar pengguna program baik secara intranet maupun internet untuk mendiskusikan materi yang ada dalam program.

Guru dapat terbantu dalam mengelola pembelajaran karena program mampu merekam semua kegiatan siswa mulai dari dia login hingga logout. Data yang direkam memuat data diri siswa, halaman yang dikunjungi lengkap dengan durasi waktu dan keseringannya, dan hasil siswa mengerjakan soal tes atau kuis. Hal ini bisa dilakukan bahkan bila siswa melakukannya di tempat yang berlainan. Siswa bisa mencetak dan menyerahkannya kepada guru sebagai tugas mandiri.

Media yang dikembangkan adalah yang berbasis web atau berbasis internet, mengingat penggunaan internet oleh semua kalangan semakin meluas. Menurut Encyclopaedia Britannica online, web atau World wide web adalah jaringan informasi yang terdiri dari sejumlah besar dokumen yang saling terhubung satu sama lain dengan dukungan link hypertext atau hypermedia, yakni hyperlinks yang memungkinkan pengguna dengan mudah mengaksesnya. Untuk bisa mengaksesnya, komputer client harus terinstall web browser. Salah satu aplikasi yang berbasis web adalah Modular Object-Oriented Dynamic Learning Environment (MOODLE). Moodle adalah aplikasi berbasis web gratis sebagai Course
Management System (CMS), juga diketahui sebagai Learning Management System (LMS) atau sebuah Virtual Learning Environment (VLE) yang mumpuni.

Dengan demikian yang dimaksud berbasis web adalah bahwa materi belajar diinstall di web server baik di komputer sendiri (local-host) maupun di perusahaan hosting menggunakan aplikasi moodle, sehingga dapat diakses oleh user dengan web browser, seperti internet explorer, mozilla, opera, dan google chrome.

\section{Pembelajaran Bahasa Inggris}

Setelah menyelesaikan pendidikannya selama tiga tahun di SMP seorang siswa diharapkan mampu memiliki kemampuan sebagai berikut (Depdiknas, 2006) (1) mendengarkan; memahami makna dalam wacana lisan interpersonal dan transaksional sederhana, secara formal maupun informal, dalam bentuk recount, narrative, procedure, descriptive, dan report, dalam konteks kehidupan sehari-hari. (2) berbicara; mengungkapkan makna secara lisan dalam wacana interpersonal dan transaksional sederhana, secara formal maupun informal, dalam bentuk recount, narrative, procedure, descriptive, dan report, dalam konteks kehidupan sehari-hari. (3) membaca; memahami makna dalam wacana tertulis interpersonal dan transaksional sederhana, secara formal maupun informal, dalam bentuk recount, narrative, procedure, descriptive, dan report, dalam konteks kehidupan sehari-hari. (4) menulis; mengungkapkan makna secara tertulis da lam wacana interpersonal dan transaksional sederhana, secara formal maupun informal, dalam bentuk recount, narrative, procedure, descriptive, dan report, dalam konteks kehidupan sehari-hari.

Dalam penelitian ini penulis mengembangkan keterampilan membaca dengan pertimbangan antara lain: Dari empat keterampilan berbahasa yang diajarkan, baru membaca yang diujikan secara nasional. Kecuali itu keterampilan membaca sangat menentukan kesuksesan belajar siapapun. Tanpa keterampilan membaca 
pemahaman yang memadai, peserta didik akan menemui kendala untuk mempelajari semua bidang. Berbagai penelitian di bidang sains mengindikasikan bahwa peserta didik yang kurang memiliki pengetahuan strategi membaca yang baik, cenderung lemah dalam memahami hal yang dipelajari (Best, Rowe, Ozura, and McNamara, 2005).

Meningkatkan kemampuan membaca dapat ditempuh dengan meningkatkan pengua-saan kosa kata. Dalam penelitiannya yang berjudul Improving Reading Comprehension Through Vocabulary, Berg, Cressman, dan Pfanz (1998) mengamati penggunaan games dan lainnya akan meningkatkan pengetahuan kosa kata yang akhirnya akan meningkatkan kemampuan membaca.

Ada banyak Pendekatan pembelajaran bahasa yang mutakhir. Richard dan Rodgers (2001) mendeskripsikan beberapa pendekatan dalam pengajaran bahasa, seperti Communicative Language Teaching, Competency-Based Language Teaching, Content-Based Instruction, Cooperative Learning, Lexical Approaches, Multiple Intelligencies, The Natural Approach, Neurolinguistic Programming, Whole Language, dan Task-Based Language Teaching. Masing-masing memiliki kelebihan dan kelemahan. Dalam penelitian ini peneliti menggunakan Task Based Learning sebagai pendekatan pembelajaran utamanya.

Task-based Learning merupakan model pendekatan pengajaran bahasa kedua yang lebih menekankan pada tasks (tugas). Task-based Language Learning (TBLL) pembelajaran bahasa berbasis tugas sering disebut Task-based Language Teaching (TBLT) atau pengajaran bahasa berbasis tugas, atau Task-based Instruction (TBI) yaitu pembelajaran berbasis tugas. Sementara itu Nunan (2004) mendefinisikannya sebagai kegiatan belajar yang melibatkan peserta didik dalam memahami, memanipulasi, memproduksi atau berinteraksi dalam bahasa target, di mana fokus gramatikalnya lebih pada mengekspresikan makna dari pada bentuk.
Pemilihan metode ini didasarkan atas kajian bahwa Task-Based Teaching memiliki beberapa prinsip dasar, diantaranya: (1) pendekatan berbasis kebutuhan; (2) penekanan pada belajar berkomunikasi melalui interaksi dalam bahasa sasaran; (3) pengenalan teks autentik pada situasi pembelajaran; (4) pemberian kesempatan bagi pembelajar untuk tidak hanya berkonsentrasi pada bahasa akan tetapi juga pada proses pembelajaran itu sendiri; (5) perluasan pengalaman pribadi pembelajar sebagai elemen yang bermanfaat pada pembelajaran di kelas; (6) menghubungkan pembelajaran bahasa di kelas dengan penggunaan bahasa di luar kelas.

Adapun hal-hal yang perlu diperhatikan pada waktu mendesain tugas Online membaca menurut Mardomingo (2004) adalah sebagai berikut: 1) harus berorientasi makna; 2) menyatakan tujuan pembelajaran dengan jelas; 3) meningkatkan kemampuan eksplorasi, improvisasi dan penemuan; 4) mengaitkan materi belajar di kelas dengan di luar kelas; 5) menjadikan peserta didik untuk terlibat secara pribadi; 6) masukkan elemen pemecahan masa-lah; 7) membantu peserta didik untuk memiliki kepedulian pada dirinya sendiri; 8) memungkinkan peserta didik untuk menjadi pembaca yang aktif.

Turino, Yuliman Purwanto, dan Arief Soeleman, (2009) yang menyempurnakan e-learning bahasa Inggris di SMA Negeri 4 Semarang mengatakan bahwa $e$ learning bahasa Inggris mampu meningkatkan kemampuan kognitif siswa apabila mempunyai tingkat interaktifitas pengguna tinggi, dan delengkapi dengan evaluasi online yang lebih bervariasi, konsultasi online maupun fasilitas chatting.

Irwan Christanto Edy (2011) dalam Studi Pemanfaatan Web Site E-Learning dan Pengaruhnya Terhadap Motivasi, Kinerja dan Hasil Belajar pada Guru dan Siswa SMK di Provinsi Jawa Tengah mengatakan bahwa pemanfaatan E-learning, yang merupakan bahasa lain dari pembelajaran berbasis Web, berpengaruh positif dan siginifikan terhadap motivasi belajar dan kinerja individu, Irwan mengatakan 
bahwa Motivasi dan kinerja individu berpengaruh positif dan signifikan terhadap hasil belajar, Namun demikian Tingkat pemanfaatan E-learning tidak berpengaruh positif terhadap hasil belajar.

Chun dan Plass (2000) dalam Brandl (2002) mengatakan bahwa kemampuan fitur umum dari WWW memungkinkan pembelajaran bahasa yang meliputi a) kemampuan umum menghadirkan materi otentik, b) kemampuan komunikasi melalui jaringan, c) kemampuan multimedia, dan d) struktur informasi non linier. Penerapan WWW dalam pembelajaran bahasa asing juga memberikan kesempatan untuk mencapai standar dengan berbagai cara (Walz, 1998) dalam Brandl (2002). Lebih lanjut Walz mengatakan bahwa penggunaan Web sejalan dengan teori belajar tentang belajar membaca material otentik

\section{Metode Penelitian}

Penelitian ini adalah penelitian dan pengembangan dengan subjek siswa SMPN 1 Ponjong kelas 8 B tahun pelajaran 2011/2012. Seluruh tahapan penelitian ini mengacu pada hasil akhir yakni terbangunnya suatu media pembelajaran membaca Bahasa Inggris SMP berbasis web yang efektif, efisien dan menarik. Dalam hal ini peneliti menggunakan model pengembangan desain pembelajaran blended berbasis web model Davidson-Shivers dan Rasmussen seperti disajikan pada Gambar 3. Dalam model ini peneliti melaksanakan 5 tahapan sebagai berikut:

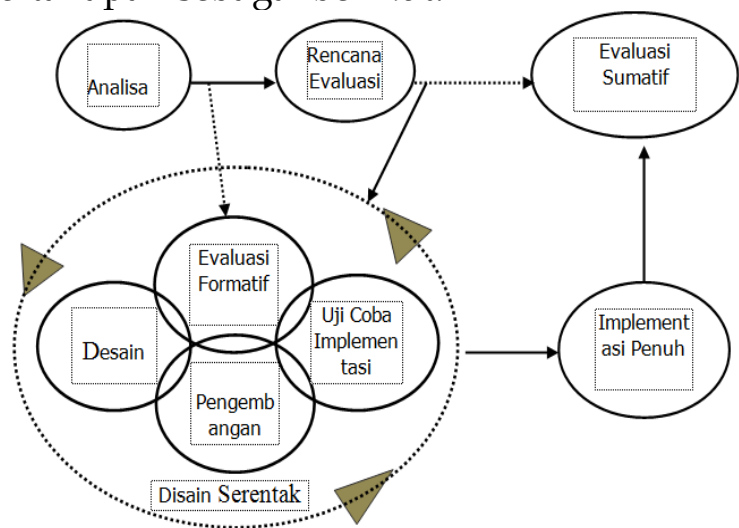

Gambar 3. Bagan Model Pengembangan Desain Pembelajaran Blended Berbasis Web (Davidson-Shivers dan Rasmussen: 2006)
Tahap Analisa Kebutuhan.

Tahap Analisa kebutuhan dilakukan untuk studi pustaka dan studi lapangan yang diperlukan untuk: pertama, menentukan materi pembelajaran yang terdiri dari: 1) standar kompetensi lulusan yang dituntut dalam Standar Kompetensi Lulusan (Depdiknas, 2006); Menentukan Standar kompetensi, kompetensi dasar (Depdiknas, 2006) dan menetapkan indikator pencapaiannya; 2) materi yang diperlukan dengan bobot yang sesuai dengan karakteristik siswa dan tuntutan standar kompetensi lulusan.

Kedua, menentukan kesiapan infra struktur, guru, peserta didik dan fasilitas lain untuk penyelenggaraan pembelajaran berbasis web. Pada tahapan ini pengembang melibatkan guru bahasa Inggris yang mengajar di SMP 1 Ponjong dan pengawas matapelajaran bahasa Inggris untuk memastikan materi yang disusun sesuai dengan tingkatan dan karakteristik siswa.

Ketiga, menentukan sofware yang akan dipergunakan. Pengembang memilih Moodle sebagai CMS (Content Management System) yang memenuhi kriteria yang telah ditentukan sebagai software utama. Moodle adalah CMS yang sangat populer dengan pengguna yang terdaftar berjumlah 68761 di 222 negara. Di Indonesia terdaftar 1133 situs. (Moodle.Org., 2012). Moodle memiliki beberapa kelebihan LMS model antara lain: 1) sederhana, efisien dan ringan serta kompatibel dengan banyak browser; 2) instalasi yang sangat mudah; 3) dukungan berbagai bahasa termasuk Bahasa Indonesia; 4) tersedianya manajemen pengguna (user management); 5) Tersedianya manajemen course ya ng baik; dan 6) Tersedianya modul chat, modul polling, forum, modul untuk jurnal, modul untuk kui, modul untuk workshop dan survey, serta masih banyak lagi.

Sebagai software pembantu, peneliti menggunakan Lectora untuk presentasi reading tips, Microsoft Powerpoint untuk presentasi tentang teks descriptive dan recount. Agar bisa dijalankan pada Moodle, file presentasi Powerpoint dikonversi dalam bentuk Scorm menggunakan software 
Wondershare. Untuk membuat quis atau tes dalam bentuk drag and drop peneliti menggunakan software Hot Potatoes yang dikemas dalam tipe Scorm. Penugasan terstruktur yang dapat diunduh, oleh peserta didik, dibuat menggunakan Microsoft Words.

Tahap Penyusunan Rencana Evaluasi.

Tahapan ini peneliti menetapkan kriteria instrumen untuk mengevaluasi produk yang dihasilkan agar memenuhi kriteria keefektifan, efisiensi dan kemenarikan sebagai acuan evaluasi formatif. Produk yang dihasilkan adalah meliputi kisi-kisi dan instrumen evaluasi oleh ahli materi; Kisi-kisi dan instrumen evaluasi oleh ahli media; dan kisi-kisi dan instrumen evaluasi oleh peserta didik. Dokumen ini sekaligus sebagai acuan evaluasi sumatif.

Tahap Pengembangan Media Serentak.

Pengembangan media serentak adalah suatu proses pengembangan yang terdiri dari empat langkah berulang, yaitu:

\section{Desain produk}

Pada tahap ini dilakukan perencanaan aktivitas dan langkah pendahuluan, isi dan penutup yang tertuang dalam garis-garis besar isi media (GBIM)

\section{Pengembangan media pembelajaran meliputi kegiatan:}

- Instalasi web server pada komputer lokal (localhost). Peneliti menggunakan paket ApacheFriends XAMPP versi 1.7.4 yang sudah mendukung Apache 2.2.17, MySQL 5.5.8, dan PHP 5.3.5.

- Instalasi Moodle versi 2.2.3 dan setting desain, pemilihan tema dan instalasi fitur utama dan pendukung. URL media ini adalah http://localhost/eng. Langkah ini dilanjutkan dengan entri tujuan pembelajaran, SK, KD dan indikator serta semua materi yang sudah disiapkan termasuk pretes, materi presentasi, kuis, dan ulangan harian.
- Setelah media dipastikan dapat dijalankan, peneliti membuat file backup agar nantinya dapat dimasukkan pada media yang diinstall pada web server internet.

- Langkah selanjutnya peneliti menyewa na-ma domain kandungs.com dengan web server pada penyedia jasa web hosting yaitu Jakarta Webhosting melalui URL http://www.jakartawebhost ing.com.

- Software Moodle diinstall menggunakan software instalasi otomatis Fantastico. Dengan software ini peneliti hanya memasukkan data dan melakukan penyesuaian, sehingga media pembelajaran membaca Bahasa Inggris SMP berbasis web dapat diakses melalui alamat URL http://www.kandungs.com/eng atau cukup dengan mengetikkan kandungs.com pada alamat browser yang digunakan.

- Setelah instalasi selesai, peneliti mengunggah file backup yang sudah dibuat sebelumnya, dan me restore pada web server yang baru bibuat. Pada langkah ini peneliti melakukan penyesuaian dan penambahan yang diperlukan sehingga produk siap diimplementasikan secara terbatas.

Uji coba implementasi produk dilakukan secara berulang sehingga produk bisa diakses dengan baik.

Evaluasi formatif. Evaluasi dilakukan oleh ahli materi, ahli media, dan uji coba terbatas. Revisi dilakukan berdasarkan masukan dan saran dari ahli materi, dan ahli media.

Fase $a, b, c$ d dilakukan berulang hingga dihasilkan produk yang memenuhi kriteria efektif, efisien dan menarik.

Implementasi penuh

Pada tahapan ini media pembelajaran Bahasa Inggris berbasis web diimplementasikan secara penuh pada kelas yang sesungguhnya setelah masukanmasukan dari beberapa ahli dianggap telah selesai. Revisi dianggap selesai apabila telah memenuhi kriteria : 1) Fasilitas-fasili- 
tas yang diperuntukkan kepada guru bahasa Inggris, peserta didik, dan administrator telah terpenuhi sebagaimana mestinya; 2) Manajemen, di mana implementasi fasilitas pengaturan-pengaturan lebih lanjut oleh guru bahasa Inggris, peserta didik, dan administrator sudah cukup, tinggal dilakukan pengaturan penyesuaian dengan karakteristik yang diharapkan.

Evaluasi sumatif.

Pada tahapan ini dilakukan desiminasi untuk peserta didik yang lebih luas, yakni mengemas program yang sudah dinyatakan layak, dan bisa disebarluaskan melalui jaringan internet untuk dijadikan media pembelajaran bahasa Inggris berbasis web di SMP

Jenis data

Adapun jenis data yang akan diperoleh dari penelitian ini adalah data kualitatif untuk mengetahui: (a) kedalaman materi dan kesesuaian dengan materi ajar dari guru mata pelajaran; (b) aspek instruksional dan kebenaran isi dari ahli materi; (c) aspek tampilan dan pemrograman dari ahli media; (d) keefektifan bahan ajar, dari unjuk kerja siswa terhadap materi berupa peningkatan prestasi belajar siswa dilihat dari hasil tes sebelumnya.

\section{Instrumen Pengumpulan Data}

Instrumen pengumpulan data yang digunakan dalam penelitian dan pengembangan ini adalah lembar observasi, wawancara, angket, dan tes. Lembar observasi dan panduan wawancara digunakan untuk menggali informasi tentang kesiapan peserta didik, guru dan infra struktur yang tersedia untuk pelaksanaan pembelajaran berbasis web. Wawancara juga digunakan untuk menggali masukan, saran, dan kritik dari ahli materi, ahli media, guru, maupun peserta didik.

Angket yang digunakan meliputi empat macam angket, yaitu angket ahli materi pada tahap pra desain serentak, angket ahli materi dalam proses desain serentak, angket ahli media, dan angket peserta didik. Angket ahli materi pra desain serentak digunakan untuk mengukur kualitas blueprint pembelajaran dan kebenaran isi sebelum dimasukkan ke dalam web. Angket ahli meteri dipergunakan untuk mengukur kualitas media pembelajaran dari aspek instruksional dan kebenaran isi. Sedangkan angket ahli media dalam proses desain serentak dimaksudkan untuk mengukur kualitas aspek tampilan dan pemrograman. Angket peserta didik dijadikan bahan untuk mengukur aspek instruksional, isi, tampilan, dan pemro-graman.

Sementara itu, tes digunakan untuk menggali data tentang keefektifan media yang dikembangkan dalam mencapai kompetensi peserta didik. Tes terdiri dua jenis, yaitu pretes yang dilaksanakan sebelum pembelajaran dan postes yang dilaksanakan pada akhir proses pembelajaran. Kedua alat tes tersebut tidak dimaksudkan sebagai alat pengumpul data eksperimen, tetapi hanya digunakan untuk memantapkan keefektiflan media yang dikembangkan.

\section{Teknis Analisis Data}

Pada uji coba pengembangan ini data yang dijaring dengan skala Likert, diolah perkomponen (indikator) dan dibandingkan dengan standar minimal yang harus dipenuhi oleh tiap komponen dalam aspek yang dianalisis. Data mentah yang diperoleh dari angket masih bersifat kualitatif. Agar juga mendapatkan data kuantitatif diadakan pemberian skor pada setiap jawaban mulai dari 1 untuk yang tidak baik hingga 5 yang terbaik.

Skor 1 untuk yang menyatakan kualitas produk sangat tidak baik, skor 2 untuk yang menyatakan kualitas produk tidak baik, skor 3 untuk yang menyatakan kualitas produk agak baik. skor 4 untuk yang menyatakan kualitas produk baik, skor 5 untuk yang menyatakan kualitas produk sangat baik.

Data yang telah terkumpul dianalisis untuk mengetahui kualitas produk pengembangan yang dihasilkan sehingga 
memenuhi standar kualitas yang baik digunakan sebagai media dan sumber belajar yang efektif, efisien dan menarik. Skor tersebut dikonversikan menjadi nilai (kategori) dengan skala 5 dengan acuan rumus sebagaimana tabel 1 (Sukardjo, 2006).
Selanjutnya data diolah dengan cara mencari nilai rata-rata dengan rumus:

$$
\begin{array}{ll} 
& \bar{X}=\frac{\sum X}{n} \\
\mathrm{X} & : \text { skor rata-rata } \\
\sum \mathrm{X} & : \text { jumlah skor } \\
\mathrm{n} & : \text { jumlah responden }
\end{array}
$$

Tabel 1. Konversi Skor Aktual Menjadi Nilai Skala 5

\begin{tabular}{clcc}
\hline Nilai & \multicolumn{1}{c}{ Kategori } & \multicolumn{2}{c}{ Interval Skor } \\
\hline A & Sangat Baik & $X>\overline{X i}+1,80 \mathrm{SB} i$ & $X>4,21$ \\
B & Baik & $\overline{X i}+0,60 \mathrm{SB} i<X \leq \overline{X i}+1,80+1,80 \mathrm{Sb} i$ & $3,4<X \leq 4,21$ \\
C & Cukup & $\overline{X i}-0,60 \mathrm{SB} i<X \leq \overline{X i}+0,60 \mathrm{SB} i$ & $2,59<X \leq 3,4$ \\
D & Kurang & $\overline{X i}-1,80 \mathrm{SBi}<X \leq \overline{X i}-0,60 \mathrm{SB} i$ & $1,79<X \leq 2,59$ \\
E & Sangat Kurang & $X \leq \overline{X i}-1,80 \mathrm{Sb} i$ & $X \leq 1,79$ \\
\hline
\end{tabular}

Keterangan:

$\overline{X i}=$ rerata skor ideal, $\mathrm{SB} i=$ simpangan baku skor ideal

$X \quad$ skor aktual

Untuk mengetahui keefektifan media yang dikembangkan dapat dilakukan dengan cara membandingkan keadaan sebelum dan sesudah menggunakan media tersebut (Sugiyono, 2012) yang digambarkan seperti gambar 4 berikut ini:

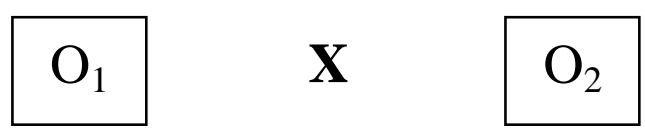

Gambar 4. Desain eksperimen (before-after)

$\mathrm{O} 1$ nilai sebelum treatment dan $\mathrm{O} 2$ sesudahnya

\section{Hasil Penelitian dan Pembahasan}

Produk yang dihasilkan

Produk yang dihasilkan adalah media pembelajaran membaca bahasa Inggris SMP berbasis web. Peserta didik dapat mengak-sesnya melalui alamat URL Error! Hyperlink reference not valid. saja. Melalui web ini peserta didik bisa memilih materi yang sesuai dengan tingkatannya, materi yang belum dikuasai. Siswa dapat menguji pemahamannya dengan mengerjakan tes atau kuis yang menyertai materi, atau mengetikkan sesuatu yang diminta oleh program. Peserta didik juga dapat mereview perkembangan belajar mereka, karena program merekam aktivitas dan nilai peserta didik. Mereka juga dapat berkomunikasi dengan teman sejawat atau berkonsultasi dengan guru melalui fitur chatting. Peserta didik harus melakukan mendaftar atau didaftar untuk mengikuti semua aktifitas yang ada dan melakukan login untuk mengawalinya.

Guru dapat mengelola pembelajaran dengan materi yang sudah ada, seperti memantau siapa saja yang sedang dan telah mengikuti aktifitas, rekap nilai semua peserta didik, dan lain sebagainya. Mereka juga mendapatkan hak untuk dapat menambah materi, kegiatan, atau evaluasi.

\section{Analisis Kebutuhan}

Berdasarkan langkah-langkah yang telah dipilih oleh peneliti, sebelum melakukan pengembangan produk, langkah pertama adalah analisis kebutuhan sebagai dasar dari tahap perencanaan pengembangan media pembelajaran bahasa Inggris berbasis web. Analisis ini meliputi ruang lingkup kajian, karakteristik peserta didik, dan sarana prasarana penunjang proses belajar peserta didik. Data analisis kebutuhan diperoleh melalui studi pustaka 
yakni kurikulum sekolah, dan studi lapangan dengan observasi dan wawancara dengan guru, pengelola lab komputer, kepala sekolah, dan peserta didik.

Ruang Lingkup Kajian

Berdasarkan kajian terhadap Standar Kompetensi Lulusan (Depdiknas, 2006), dan Standar Isi (Depdiknas, 2006) diperoleh data bahwa terdapat empat aspek keterampilan berbahasa; yakni mendengarkan (listening), berbicara (speaking), membaca (reading), dan menulis (writing). Dari keempat aspek keterampilan berbahasa tersebut, yang diujikan dalam Ujian Nasional adalah membaca dan menulis. Membaca mendapatkan porsi $70 \%$ dan sisanya, $30 \%$, menulis. Berdasarkan analisis tersebut, peneliti menganggap penting untuk mengembangkan media pembelajaran membaca Bahasa Inggris SMP berbasis web.

Kajian tersebut diperkuat dengan hasil wawancara dengan guru dan peserta didik yang mengatakan bahwa materi pelajaran keterampilan membaca perlu mendapat prioritas utama. Baik guru maupun peserta didik mengatakan bahwa sangat diperlukan adanya media keterampilan membaca untuk membantu pemahaman peserta didik dalam mengerjakan soal ujian yang sebagian besar adalah membaca. Keterampilan membaca juga diperlukan oleh peserta didik dalam memperoleh sumber belajar melalui internet.

Karena yang diharapkan peserta didik dan guru untuk membantu peserta didik dalam memahami bacaan, maka peneliti mengambil salah satu Standar Kompetensi (SK) 5 (membaca) yakni "Memahami makna teks tulis fungsional dan esei pendek sederhana berbentuk descriptive dan recount yang berkaitan dengan lingkungan sekitar" dengan kompetensi dasar (KD) 5.3. "Merespon makna dan langkah retorika dalam esei pendek sederhana secara akurat, lancar dan berterima yang berkaitan dengan lingkungan sekitar dalam teks berbentuk descriptive dan recount"
KD ini berkaitan dengan membaca pemahaman.

Untuk memastikan materi pembelajaran bahasa Inggris yang sesuai dengan karakteristik peserta didik, peneliti juga melakukan brain-storming dengan guruguru bahasa Inggris SMP dalam forum MGMP Kabupaten Gunungkidul dan pengawas mata pelajaran bahasa Inggris, dan guru mata pelajaran bahasa Inggris SMP 1 Ponjong Gunungkidul.

\section{Karakteristik peserta didik}

Berdasarkan observasi dan wawancara, peneliti menyimpulkan bahwa peserta didik memiliki kemampuan dasar yang cukup untuk memanfaatkan teknologi informasi, khususnya internet untuk kegiatan belajar mereka. Peserta didik juga sudah terbiasa memanfaatkan internet, baik untuk menyelesaikan tugas-tugas maupun untuk sekedar mencari informasi umum dan berkomunikasi melalui email dan jejaring sosial seperti Facebook dan Twitter.

Sarana prasarana penunjang belajar peserta didik

Berdasarkan wawancara dengan guru bahasa Inggris, pengelola lab komputer, dan kepala sekolah SMP 1 Ponjong, kecuali yang berkaitan dengan materi pembelajaran, diperoleh informasi tentang kesiapan infra struktur, guru, peserta didik dan fasilitas lain untuk penyelenggaraan pembelajaran berbasis web. Fasilitas yang mendukung pembelajaran berba-sis web, bisa dipergunakan baik secara intranet maupun internet. Jumlah LCD Projector, Local Area Networks (LAN), perangkat Wifi hotspot dan jaringan internet cukup memadai. Demikian juga dukungan kepala sekolah yang berkaitan dengan kebijakan e-Learning baik secara eksplisit maupun implisit lebih menguatkan untuk penerapan pembelajaran berbasis web. Pengelola TIK di sekolah yang secara teknis terus menerus membimbing guru-guru melalui pendampingan dan pelatihan dalam mengoptimalkan penggunaan sarana prasarana tersebut. 
Sumber-sumber belajar dan referensi untuk Pengembangan media pembelajaran membaca Bahasa Inggris SMP berbasis web berbentuk teks, gambar, animasi, audio, dan video diperoleh dari buku, majalah, jurnal, artikel, bahan pelatihan, baik dalam bentuk cetak maupun elektronik. Berikut ini adalah sumber referensi yang dipergunakan sebagai acuan:

- Permendiknas Nomor 23 tahun 2006 tentang Standar Kompetensi Lulusan.

- Permendiknas Nomor 22 tahun 2006 tentang Standar Isi

- Permendiknas Nomor 41 tahun 2007 tentang Standar Proses

- Permendiknas Nomor 20 tahu 2007 tentang Standar Penilaian

- Buku Pelajaran Bahasa Inggris untuk Kelas 8

- Buku Sekolah Elektronik

Perancangan evaluasi

Dalam rencana evaluasi, peneliti menentukan instrumen evaluasi formatif yang dalam waktu yang bersamaan berkaitan dengan evaluasi formatif dan sumatif. Instrumen ini untuk mengetahui keefektifan (effectiveness), efisiensi (efficiency) dan kemenarikan (Appeal). Intrumen ini diperuntukkan ahli materi ahli media, dan peserta didik yang menggunakan web ini.

Kelayakan Media Pembelajaran

Kelayakan media pembelajaran yang dikembangkan dinilai dari evaluasi yang dilakukan oleh ahli materi yang meliputi aspek instruksional dan isi, evaluasi ahli media melipuri aspek tampilan dan pemrograman. Sementara hasil penilaian peserta didik meliputi aspek instruksional, isi, tampilan dan pemrograman.

Data hasil evaluasi ahli materi dari aspek instruksional menunjukkan bahwa semua indikator dinyatakan layak. Dari 14 indikator, 1 indikator masuk kategori sangat baik dengan rata-rata skor 4,5 yaitu kejelasan petunjuk belajar; sepuluh indikator masuk kategori baik dengan skor 4 yaitu ketepatan materi atau isi dan relevansinya dengan standar kompetensi; ketepat- an materi atau isi dengan kompetensi dasar; ketepatan materi yang dimediakan; urutan materi; kesesuaian latihan dengan kompetensi dasar; kesesuaian latihan dengan indikator; penggunaan bahasa dalam menjelaskan konsep, materi, dan latihan soal; variasi bentuk soal; keseimbangan materi dengan soal latihan; dan pemberian motivasi belajar lewat kuis. Sedangkan 3 indikator masuk kategori cukup baik dengan skor 3,5 yaitu kejelasan sasaran produk (target audience), kecukupan materi, kejelasan materi/konsep, dan pemberian motivasi belajar lewat kuis. Hal berarti bahwa indikator-indikator aspek pembelajaran layak untuk diimplementasikan secara penuh.

Jumlah skor dari kedua ahli materi menunjukkan angka yang cukup tinggi. Ahli materi pertama memberikan total skor 53 dan ahli materi kedua 54. Rata-rata skor untuk masing-masing ahli materi adalah 3,79 dan 4,15. Jumlah skor keseluruhan adalah 53,5 dengan rata-rata skor 3,97. Kategori produk "Media Pembelajaran membaca Bahasa Inggris SMP berbasis web" dari aspek instruksional masuk kategori baik, sehingga layak untuk diimplementasikan secara penuh ke tahap selanjutnya dengan revisi sesuai yang disarankan.

Aspek kebenaran isi juga menunjukkan hasil yang positif dan dinyatakan layak untuk diujicobakan ke tahap selanjutnya. Hasil evaluasi ahli materi membuktikan pernyataan tersebut. Dari 11 indikator, 1 indikator mendapatkan skor rata-rata 4,5. Indikator tersebut adalah "contoh-contoh realistis dalam merumuskan konsep atau kejelasan materi". Tujuh indikator yang masuk kategori baik (4) adalah kebenaran isi; kecukupan materi; kejelasan materi/konsep; urutan materi; konsistensi penyajian; petunjuk pengerjaan soal; kejelasan soal. Sedangkan 3 indikator yang masuk kategori cukup baik $(3,5)$ adalah kejelasan dan kelugasan bahasa; keseimbangan materi dengan soal latihan; fasilitas simulasi untuk penguatan dan pemahaman konsep .

Ahli materi pertama memberikan total skor 41, sedangkan ahli materi kedua 
memberikan skor 45 . Jumlah skor keseluruhan adalah 43 dengan rata-rata skor 3,91. Apabila rata-rata skor tersebut dikonfirmasikan pada Skala Likert, skor tersebut masuk kategori baik. Hal ini dapat diartikan bahwa produk "Media Pembelajaran membaca Bahasa Inggris SMP berbasis web" dari aspek kebenaran isi layak untuk diimplementasikan secara penuh.

Secara keseluruhan, materi pembelajaran yang sudah diunggah pada server internet dengan alamat URL http://www. kandungs.com/eng dinyatakan sudah layak oleh ahli materi. Rancangan penyajian materi cukup baik, sehingga sajian materi tersebut memudahkan peserta didik dalam mempelajari standar kompetensi membaca. Kualitas penilaian materi media tersebut dapat visualisasikan pada Gambar 5.

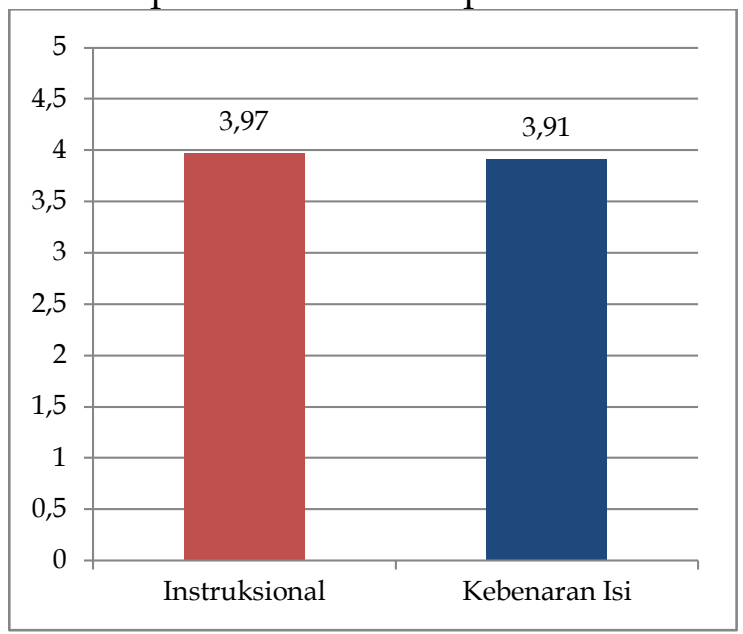

Gambar 5. Kualitas Media Pembelajaran Membaca Bahasa Inggris SMP Berbasis Webhasil Evaluasi Ahli Materi

\section{Analisis Data Hasil Penilaian Ahli Media}

Hasil evaluasi ahli media menunjukkan bahwa skor aspek tampilan, khususnya "kejelasan narasi", "keterbacaan teks", "komposisi setiap halaman/slide", dan "konsistensi penyajian" masuk kategori sangat baik, yaitu 4,50. Sementara itu, indikator yang lain termasuk kategori baik dengan skor 4,00. Total skor rata-rata untuk keseluruhan indikator adalah 50,00 dari skor maksimal 60. Skor rata-rata untuk semua indikator adalah 4,17 atau kategori baik, sehingga produk tersebut layak untuk diujicobakan pada tahap berikutnya.
Hasil reviev aspek pemrograman menunjukkan bahwa "optimalisasi interaksi", "efisiensi setiap halaman/slide, "ketepatan penggunaan hyperlink", "layanan dukungan teknis" dan "kebebasan memilih materi yang akan dipelajari" memperoleh skor rata-rata 4,50. Artinya kelima indikator tersebut termasuk kategori sangat baik, sedangkan indikator-indikator yang lain masuk ke dalam kategori baik dengan skor 4,00. Total skor rata-rata keseluruhan 59,50 dari skor maksimal 70,00. Untuk keseluruhan, skor rata-rata kualitas pemrograman adalah 4,25 atau ketegori baik. Gambar 6 menunjukkan hasil evaluasi ahli media secara keseluruhan.

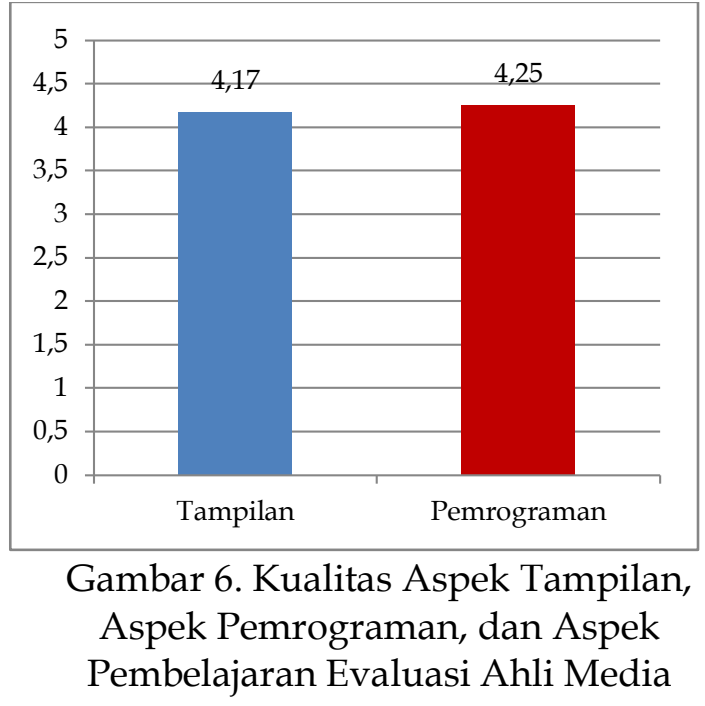

\section{Analisis Data Hasil Penilaian Peserta Didik}

Hasil penilaian dari peserta didik menunjukkan hasil yang signifikan pada keempat aspek yang dinilai. Aspek pertama, kualitas instruksional secara implisit dinyatakan layak oleh responden. Hal itu ditunjukkan hasil skor secara keseluruhan. Skor keseluruhan uji coba kelompok kecil mencapai skor rata-rata 40,33 dari total skor maksimal 50 untuk 10 indikator. Skor rata-rata hasil yang diperoleh adalah 4,03, dengan kategori baik. Aspek kedua, kualitas isi juga dinyatakan layak oleh responden. Hal itu ditunjukkan hasil skor secara keseluruhan yang mencapai skor rata-rata 36,33 dari total skor maksimal 40 dari 9 indikator. Skor rata-rata hasil yang diperoleh adalah 4,04, dengan kategori baik. Aspek ketiga, kualitas tampilan, mencapai 
skor rata-rata 52 dari total skor maksimal 65 untuk 13 indikator. Skor rata-rata hasil yang diperoleh adalah 4,00, dengan kategori baik. Aspek keempat, kualitas pemrograman mencapai skor rata-rata 49,33 dari total skor maksimal 60 untuk 12 indikator. Skor rata-rata hasil yang diperoleh adalah 4,11, dengan kategori baik.

Kualitas produk secara keseluruhan mendapat skor 177,99 dari total skor rata-rata maksimal 220. Rata-rata skor 4,13 atau terma-suk kategori baik. Artinya, penilaian peserta didik menghasilkan data yang menunjukkan tingkat kelayakan produk. Untuk memperjelas uraian di atas, berikut disajikan diagram batang kualitas produk hasil penilaian peserta didik.

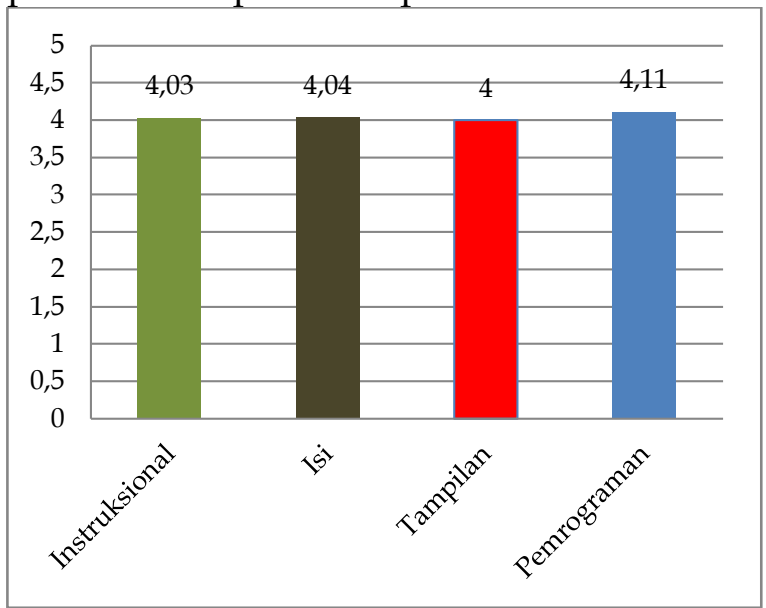

Gambar 7. Diagram Kualitas Media Pembel-ajaran Membaca Bahasa Inggris SMP Berbasis Web Hasil Penilaian Peserta didik

Meskipun demikian, evaluator memberikan beberapa masukan untuk perbaikan program. Masukan tersebut adalah sebagai berikut: (1) perlunya peningkatan sisi user friendly, sehingga sistem bisa berdialog dengan pengguna seramah mungkin (menyenangkan dan mudah digunakan); (2) sebaiknya banner dibuat image yang lebih menarik.

Peneliti juga memperhatikan ungkapan dosen pembimbing yang secara implisit menyarankan untuk lebih mempermudah akses pembelajaran ini dengan cara sebagai berikut: (1) perlunya perbaikan pada alamat URL sehingga tidak ada pesan kesalahan; (2) perlunya perbaikan pada course enrolment, sehingga peserta didik dapat mengerjakan quiz, latihan atau tes dengan tanpa melalui langkah yang rumit.

\section{Analisis Keefektifan Produk}

Untuk menguji keefektifan produk, peneliti menggunakan pretes dan postes kompetensi dasar materi yang dimediakan, yakni keterampilan membaca. Tingkat penguasaan awal peserta didik terhadap kompetensi dasar ini sebelum mendapat perlakuan sangat rendah. Nilai Pretes tertinggi hanya 70 , sedangkan nilai terendah 20 dengan rata-rata 43. Jika nilai tersebut dibandingkan dengan nilai ketuntasan minimal mata pelajaran Bahasa Inggris di SMP 1 Ponjong, yaitu 70, peserta didik yang mencapai ketuntasan hanya 1 orang $(4 \%)$. Setelah peneliti bersama guru bahasa Inggris memberikan materi menggunakan media berbasis web, hasil tes akhir menunjukkan peningkatan yang cukup signifikan. Nilai tertinggi yang diperoleh peserta didik adalah 100, sedangkan nilai terendah 63 dengan nilai rata-rata 86 dengan daya serap klasikal 86\%. Tingkat ketuntasan secara klasikal adalah 26 orang (90\%), menunjukkan perbedaan yang sangat signifikan. Dengan demikian maka diambil kesimpulan bahwa media pembelajaran membaca Bahasa Inggris SMP berbasis web terbukti memiliki keefektifan yang tinggi.

Produk "Media Pembelajaran membaca bahasa Inggris SMP berbasis web" yang telah dikembangkan mempunyai kelebihan-kelebihan, sebagai berikut.

Pertama, produk "Media Pembelajaran membaca bahasa Inggris SMP berbasis web" memiliki tingkat kelayakan sebagai media pembelajaran yang baik. Hal ini dibuktikan dari hasil review ahli dan uji coba, maupun implementasi lapangan. Semua indikator yang ada pada aspek-aspek yang diuji-cobakan memperoleh nilai ratarata di atas batas minimal atau masuk kategori baik dan sangat baik. Hal tersebut menandakan bahwa produk yang dihasilkan oleh pengembang layak untuk dimanfaatkan oleh guru dalam proses pembelajaran di kelas. 
Kedua, kualitas produk yang masuk kategori baik membawa dampak dalam meningkatkan prestasi belajar $\mathrm{p}$ eserta didik. Hasil tes menunjukkan bahwa peserta didik mampu meningkatkan ratarata hasil belajar dari $43 \%$ menjadi $86 \%$ dengan tingkat ketuntasan secara klasikal $4 \%$ menjadi $90 \%$. Dengan demikian dapat diartikan bahwa tingkat keefektifan produk sangat baik.

\section{Keterbatasan Penelitian}

Media pembelajaran membaca Bahasa Inggris SMP berbasis web yang dihasilkan mempunyai beberapa keterbatasan.

- Produk lebih banyak mengukur ranah kognitif dibandingkan ranah afektif dan psikomotorik. Demikian juga soal evaluasi dalam program ini belum mampu mengukur kompetensi dasar yang berkaitan dengan dua ranah tersebut dengan menyeluruh. Hal ini disebabkan oleh keterbatasan pengetahuan pengembang dalam membuat program

- Media pembelajaran ini hanya diujicobakan pada responden di satu sekolah. Secara umum, kesimpulan yang diambil oleh pengembang sangat mungkin belum dapat mewakili seluruh peserta didik SMP/MTs. kelas VIII pada umumnya.

- Pemilihan materi, pengembangan, kegiatan belajar dan evaluasi mungkin belum mencukupi untuk penguasaan kompetensi dasar yang ditetapkan sehingga pembelajaran masih memerlukan peran guru di kelas. Dalam hal ini, guru harus menambah materi, kegiatan belajar dan evaluasi melalui perannya sebagai pengelola pembelajaran. Dengan demikian, media pembelajaran membaca bahasa Inggris SMP berbasis web ini memenuhi tuntutan pencapaian kompetensi dasar.

- Proses uji coba untuk mengetahui tingkat keefektifan produk terbatas pada kelas eksperimen saja tanpa melibatkan kelas kontrol sebagai pembanding.

\section{Simpulan dan Saran}

Simpulan

Berdasarkan hasil penelitian dan pembahasan, pengembangan ini dapat disimpulkan sebagai berikut.

Pertama, pengembangan media pembelajaran membaca Bahasa Inggris SMP berbasis web ini menghasilkan produk yang telah memenuhi kelayakan untuk digunakan pada proses pembelajaran peserta didik. Hal ini didasarkan pada evaluasi ahli materi yang meliputi aspek instruksional dengan skor 3,97 dan aspek kebenaran isi dengan skor 3,91, dengan rata-rata sebesar 3,94 atau kategori baik. Sedangkan evaluasi yang dilakukan ahli media yang meliputi aspek tampilan dengan skor 4,17 dan aspek pemrograman dengan skor 4,25 dengan rata-rata 4,21 atau kategori baik. Sementara itu, hasil uji coba peserta didik memperoleh skor rata-rata sebesar 4,13 atau kategori baik.

Kedua, hasil pretes dan postes menunjukkan bahwa peserta didik mampu meningkatkan rata-rata hasil belajar dari $43 \%$ menjadi $86 \%$ dengan tingkat ketuntasan secara klasikal 4\% men-jadi 90\%. Media pembelajaran membaca Bahasa Inggris SMP berbasis web yang dikembangkan terbukti efektif.

Saran

Media pembelajaran bahasa Inggris berbasis web ini dapat digunakan sebagai salah satu alternatif sumber dan media pembelajaran bahasa Inggris di SMP, baik secara individu maupun kelompok, baik di dalam kelas maupun di luar kelas dengan pantauan dan bantuan guru secara online.

\section{Diseminasi}

Diseminasi dapat dimulai dari tingkat yang paling bawah yaitu siswa. Media pembelajaran bahasa Inggris SMP ini dapat diakses melalui komputer sekolah, warnet, atau bahkan komputer peserta didik dari rumahnya masing-masing, sehingga peserta didik dapat mempelajari materi setiap saat. Secara lebih luas, guru 
bersama sejawat melalui forum MGMP (Musyawarah Guru Mata Pelajaran) tingkat sekolah, kecamatan, kabupaten, bahkan ke tingkat yang lebih luas lagi.

\section{Pengembangan Produk Lebih Lanjut}

Diperlukan adanya penelitian serupa untuk mengetahui tingkat kelayakan produk dengan responden yang lebih luas dengan melibatkan kelompok kontrol dari beberapa sekolah, sehingga hasil uji coba lebih valid.

Program ini adalah program terbuka yang melibatkan guru untuk bukan saja mengelola pembelajaran dengan materi yang sudah ada, tetapi dapat menambah materi, kegiatan, atau evaluasi. Kemajuan teknologi yang pesat membawa dampak positif bagi pengembangan sumber dan media pembelajaran dan pemanfaatannya. Pengembangan serupa diharapkan dapat dilakukan untuk kompetensi dasar yang lain atau mata pelajaran yang lain agar peserta didik lebih mudah memahami materi secara keseluruhan. Pengembangan dapat dilakukan secara bersama-sama dengan guru matapelajaran sejenis dari sekolah atau rumah masing-masing.

\section{Daftar Pustaka}

Berg, A., Cressman, K.S., \& Pfanz, T. (1998). Improving Reading Comprehension Through Vocabulary. (ERIC Documentation No. ED 420 051)

Best, R.M., Rowe, M., Ozuru, Y., \& McNamara, D.S. (2005). Deep-level comprehension of science text. Topics in language Disorders, 25(1), 65-83.

Brandl, K. (2002). Integrating internetbased reading materials into the foreign language curriculum: From teacher- to student-centered approaches. Language Learning $\mathcal{E}$ Technology Vol. 6, No.3, September, 87-107.

Depdiknas. (2006). Peraturan menteri pendidikan nomor 22 Tahun 2006, tentang standar isi untuk satuan pendidikan dasar dan menengah.

Depdiknas. (2006). Permendiknas no. 23 tahun 2006, tentang standar kompetensi lulusan.

Edy, I. C. (2011). Studi pemanfaatan web site e-learning dan pengaruhnya terhadap motivasi, kinerja dan hasil belajar pada guru dan siswa SMK di Provinsi Jawa Tengah. Dipetik 5 18, 2012, dari http:/ / e-journal.stieaub.ac.id/index.php/probank/artic le/download/2/28

Jack C. Richards and Theodore S. Rodgers (2001) Approaches and methods in language teaching (2nd ed.). Cambridge: Cambridge University Press.

Mackey, W. F. (1985). Language teaching analysis, 107-124. London: Longman Group Ltd.

Mardomingo, C. R. (2004). Trayectorias: A new model for online taskbased learning. ReCALL,145157 doi: 10.1017 / S0958344004001119.

Moodle.Org. (2012, 10 21). Registered moodle sites. Dipetik 10 21, 2012, dari Moodle: https://moodle.org/sites/ index.php?country=ID

Nunan, D. (2004). Task-based language teaching. Cambridge. Cambridge: Cambridge University Press.

Sugiyono. (2012). Penelitian pendidikan-Pendekatan kuantitatif, kualitatif, dan $R \mathcal{E D}$. Bandung: Alfabeta.

Sukardjo. (2006). Kumpulan materi evaluasi pembelajaran. Yogyakarta: Jurusan Teknologi Pembelajaran, Program Pascasarjana, Universitas Negeri Yogyakarta.

Sumarno, Alim. (2011). Desain pengembangan pembelajaran blended berbasis web model Davidson-Shivers $\mathcal{E}$ Rasmussen. Dipetik 4 16, 2012, dari Media Pendidikan Teknologi Pendidikan Universitas Negeri Surabaya: http://blog.tp.ac. $\quad$ id/desainpengembangan-pembelajaran- 
blended-berbasis-web-modeldavidson-shivers-danrasmussen\#ixzz2CYX6zd-92

Surjono, H. D. (2010). Membangun course e-learning berbasis Moodle. Yogyakarta: UNY Press.
Widiati, U. (Desember 2010). Pidato pengukuhan guru besar dalam bidang ilmu-ilmu teaching English as a Foreign Language pada Fakultas Sastra Universitas Negeri Malang (UM), pada tanggal 16 Desember 2010, di Aula Utama, Gd. A3 Lt. II UM, Jalan Sema-rang 5 Malang 